\title{
Transformation of Ulama's Role in Nusantara: A Case Study of Halalan Thayyiban Food Law in Indonesia
}

Ikomatussuniah, Mohammad Reevany Bustami, Wani Maler, Moh. Mudzakkir

To Link this Article: http://dx.doi.org/10.6007/IJARBSS/v11-i4/9693 DOI:10.6007/IJARBSS/v11-i4/9693

Received: 06 February 2021, Revised: 10 March 2021, Accepted: 25 March 2021

Published Online: 21 April 2021

In-Text Citation: (Ikomatussuniah et al., 2021)

To Cite this Article: Ikomatussuniah, Bustami, M. R., Maler, W., \& Mudzakkir, M. (2021). Transformation of Ulama's Role in Nusantara: A Case Study of Halalan Thayyiban Food Law in Indonesia. International Journal of Academic Research in Business and Social Sciences, 11(4), 447-462.

\section{Copyright: @ 2021 The Author(s)}

Published by Human Resource Management Academic Research Society (www.hrmars.com)

This article is published under the Creative Commons Attribution (CC BY 4.0) license. Anyone may reproduce, distribute, translate and create derivative works of this article (for both commercial and non-commercial purposes), subject to full attribution to the original publication and authors. The full terms of this license may be seen at: http://creativecommons.org/licences/by/4.0/legalcode

\section{Vol. 11, No. 4, 2021, Pg. 447 - 462}




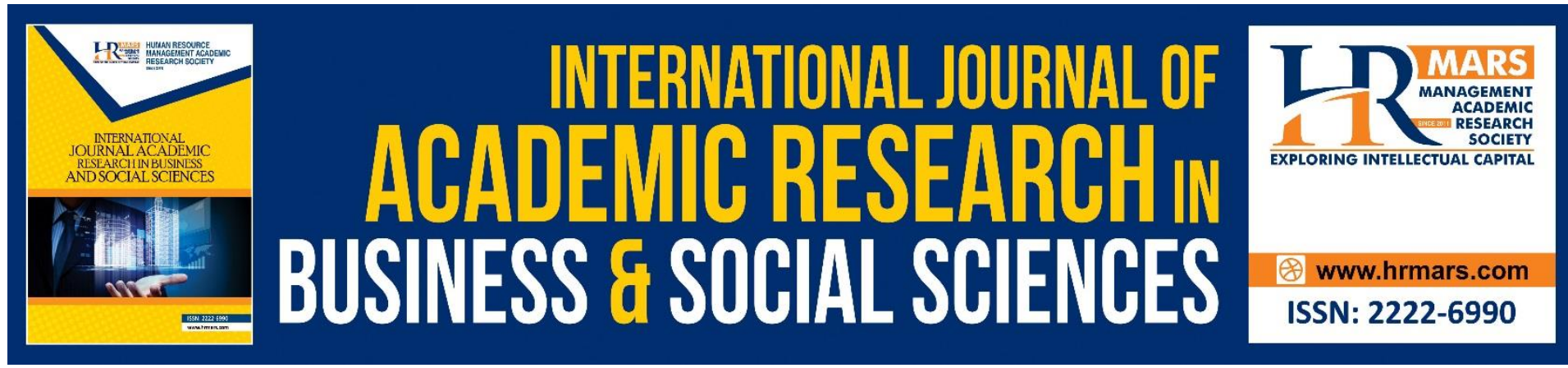

\title{
Transformation of Ulama's Role in Nusantara: A Case Study of Halalan Thayyiban Food Law in Indonesia
}

\section{Ikomatussuniah}

Centre for Policy Research and International Studies (CenPRIS) Universiti Sains Malaysia, Malaysia, PUI-PT Ketahanan Pangan, ICEFORY, Universitas Sultan Ageng Tirtayasa, Indonesia

\author{
Mohammad Reevany Bustami \\ Centre for Policy Research and International Studies (CenPRIS) Universiti Sains Malaysia, \\ Malaysia
}

Wani Maler

Centre for Global Archaeological Research (PPAG), Universiti Sains Malaysia, Malaysia

\section{Moh. Mudzakkir}

Department of Sociology, Faculty of Social Sciences and Law, Universitas Negeri Surabaya, Indonesia

\begin{abstract}
The history of halalan thayyiban food in Indonesian society is an undone research study. This research is to study the transformation of scholars' (ulama) roles based on the history of halalan thayyiban food law in Indonesia's society. The method used was qualitative data analysis using archival research for the history of halalan thayyiban food and in-depth interviews conducted with figures of several religious-based organisations in BantenIndonesia to strengthen the results. The respondents were leaders from Muslim and NonMuslim organisations in Banten Province. In addition, the recorded conversation transcribed was used to support the findings. The results found that the ulama roles in the halal standard are different in three levels of eras. In the pre-colonial period, scholars acted as exemplars of Islam by applying Islamic values in people's daily lives, including the concept of halalanthayyiban food, based on the Islamic boarding school educational system. Scholars became missionaries in the colonial era, who are believed to be enforcers of Islamic law. The colonisers did not interfere in the rules of religion, especially on halalan thayyiban food law. During this period, Islamic law became a custom that developed in the community. Next, the post-colonial era, when the role of scholars on halalan thayyiban food standard is done by issuing halal certificates based on halal fatwas. The government intervened to legalize it under
\end{abstract}


public law. The results contributed theory to fill the gap of knowledge about the transformation of ulama roles on halalan-thayyiban food law in Indonesia.

Keywords: Halalan Thayyiban Food, Law, Ulama, Indonesia, History

\section{Introduction}

Muslim traders first arrived at the trading centres in Nusantara by sea route. Those who came could not go straight back to where they came from, as they had to wait for about six months for the change of wind to sail back. During that time, they waited for their goods sold, then purchased local products and brought it back to their home country. Muslim traders came in groups and lived in villages close to the city port (Tjandrasasmita, 2009).

Muslim traders began to introduce Islamic teachings to the surrounding communities along the coastal areas (Lapidus, 2000). Interaction between Muslim traders and local communities was carried out gradually. It was through communication that the process of Islamization transferred. The account of Tome Pires (1944) explained that the merchants married local women during their stay, which then Muslim families were formed from those marriages. From an economic point of view, foreign Muslim traders gained high status and position, eventually, the nobility and kings tended to marry their daughters to Muslim traders. Moreover, the king would be invited to embrace Islam, then the habits and behaviour of the king who carried out the teachings of Islam were followed by the people. The situation made Islam spread instantly in Nusantara. Furthermore, the Islamic teachings began to be conveyed including related to the principle of halalan thayyiban food.

Around the 15th and 16th centuries, areas that previously under the rule of the HinduBuddhist kingdoms were gradually converted to Islam. In this process, Islam succeeded in bringing a education system to the community accessible to all levels of society. This education system introduces the Qur'an and al-Hadith, as well as Arabic script writing that was taught evenly to all people, started from the simplest stage. The recitation of the Quran was taught, began with introduction of the Hijaiyah letters, as well as the practice of worship, and Islamic morals. Ulama(s) or kiayi(s) called as scholar(s) that have the authority to deliver knowledge (Ambary, 1998).

Furthermore, around the $5^{\text {th }}$ Hijri, there have been Sufi among the advocators of Islam who came to Indonesia. In the 14th century and later, Islam developed from the west, namely Sumatra and Java, to the east, namely Kalimantan, Sulawesi, and Nusa Tenggara, which were carried out by Indonesian mubaligh (ulama) such as Sunan Prapen, Khatib Dayan, Dato ri Bandang, and Dato Sulaeman. It arose from the occurrence of the initial phase with the maritime trade process that has been take place. Furthermore, the Muslim community was accreting followed by the socialization of Islamic teachings until widely accepted in Indonesia (Ambary, 1998).

As in Indonesia, colonial could not impose law in the form of civil law (Meulen, 2011). People in Indonesia already have older laws and are rooted in their daily lives, namely customary law. Thus, they can only "let go" the rule that it brought juxtaposed with the common law that existed long before they came due to the legal transformation in food regulation. During the kingdom period, food was regulated by the king related to micro-way food security with food self-sufficiency in its time. People can meet their food needs independently and they were required to pay tribute to the king after every harvest each year (Munoz, 2009). Micro-way is the interaction between people to meet food needs other than rice -clothes for instance, and it is done by a barter system. The land processing up to the planting was performed at the time according to the customs and customary law that take 
place in the area. Then, Muslim merchants from India and the Middle East came to interact, trade, and socialize with the local community so that Islamic values spread,

This theory was later developed by Snouck Hurgronje who argued, once Islam was firmly based in several port cities of the Indian Subcontinent, Deccan Muslims -many of them lived there as intermediary traders in the Middle East trade with the Nusantara-came to the Malay world-Indonesia as the first propagandists of Islam. Then, they were followed by Arabs -mostly descendants of the Prophet Muhammad SAW due to using the title sayid or syarif- who completed the spread of Islam in the Archipelago. These Arabs appeared in Nusantara both as "priests" and as "priests princess" or sulthan. Snouck Hurgronje does not explicitly mention which region in South India that he views as the origin of Islam in the Archipelago. But, he calls the 12th century is the most likely period from the beginning of the spread of Islam in the Archipelago (Azra, 2013).

Based on the explanation above, the grouping of the period to describe the transformation of roles of scholars on halalan thayyiban food law divided into three time periods:

a. Pre-colonial period occurred before the 16th century AD

b. The colonial period during the 16th century to the beginning of the 20th century AD

c. Post-colonial occurred after the 20th century AD until now.

Eventually, the research question is what the transformation appears of the ulama's roles regarding halalan thayyiban food law on three levels of periods, namely pre-colonial, colonial, and post-colonial. The results may fill the gap of knowledge on the evolution of ulama's roles on halalan thayyiban food law, based on a case study in Indonesia.

\section{Literature Review}

\section{Halalan Thayyiban Food in Indonesia}

Meulen (2011) stated that "Western science states, "the food chain from farm to fork" as an existing rule that it is customary in meeting food needs based on local wisdom". Hence, the food law has been institutionalized by the ruler over time, and the development of needs in the community, especially about the rules and laws of halalan thayyiban food for Muslims. Concerning the point of view, there are various theories about the coming of Islam as explained by Azyumardi Azra (2013) in his book, that, "there are a long discussion and debate among experts on three main issues: the origin place of the Islam coming from, its bearers, and the time of its arrival." Furthermore, in other literature, it is said that,

There is no agreement among historians regarding to when Islam began to enter and spread in the Malay world. Existing theories are divided into two categories. Some say that the arrival of Islam was in the first Hijri or $7^{\text {th }}$ AD. The perspective of this first category explained by W.P. Groeneveldt, T.W. Arnold, Syed Naguib al-Attas, George Fadlo Hourani, J.C. van Leur, Hamka, Uka Tjandrasasmita, and others. The other theory said that the coming of Islam was on the $13^{\text {th }} A D$. This second category theory was put forward by C. Snouck Hurgronje, J.P. Moquette, R.A. Kern, Haji Agus Salim, and others (Tjandrasasmita, 2009).

The process of spreading of Islam in the Archipelago, including in Indonesia, is carried out through trade, marriage, bureaucracy, education (pesantren), sufism, art, and other aspects (Tjandrasasmita, 2009). Islamic values spread culturally, including the dissemination of the principle of halalan thayyiban food law. Based on this, people interact by using religious 
norms containing Islamic teachings applied in their daily lives. Moreover, the historical perspective said that ( Ambary, 1998),

From historical studies, the role of ulama and pesantren (Islamic boarding school) in Indonesia can be traced chronologically, as follows:

1. 12th to mid-15th century $A D$, pesantren developed as a means of socialization of Islam and education of scholars and leaders. In this phase, scholars from outside Indonesia play a role in proclaiming the territory of Indonesia.

2. Late 15th to mid-16th century $A D$, pesantren became one of the education centres and preparation of elite cadres of the royal bureaucracy, and local scholars have become spreaders of Islam in Indonesia.

3. Mid-16th century to mid-17th century AD. Scholars and pesantren became a tool of the legitimacy of power.

4. Mid to late 17th century $A D$ began to appear competition between pesantren (ulama) and bureaucratic elites. Especially, when the center of Islam shifted inland (Islamic Mataram)

5. The end of the 17 th century until the end of the 18 th century AD. The role of scholars as a reference for legitimacy is one of the tools of the elite government bureaucracy.

6. The phenomenon of the history at the end of the 18th century showed that some of the boarding schools were destroyed (Kajoran, Giri, Sumenep).

7. At the end of the 18th to 19th centuries, pesantren shifted from a center of power to became an extension of the hand of colonialism, while pesantren became the foundation of people's aspirations again.

Modern developments today are inseparable from the development of history, It is understood that modern organizations in Indonesia and Malaysia were rooted in ancient kingdoms that flourished 1500 years ago on the islands' coasts. In most social aspects as well as in the political programs of its rulers today, modern countries have developed an enormous social and economic continuity with their predecessors. Studying ancient kingdoms can provide some key to understanding these modern countries. Thanks to the increasingly advanced access to information, historical studies can now easily integrate the various field of research; from archaeology to philology, ethnography, economics, etc., complex new models can now be created and tested. Contrary to the old colonial model, which spread the idea that cultural evolution occurred through the diffusion of more technically and culturally advanced foreign communities (colonial), these new theories tend to propose various factors in explaining the development and evolution of society in Southeast Asia (Munoz, 2009).

Historical development from the kingdom, the colonial to the modern eras is inseparable from interactions of indigenous people. Indigenous people are a group of people who come from one place and develop over a long period in a place that conducts sociocultural, economic, and even religious interactions continuously, and they have their group as their identity. The community is led by a leader who has a significant set of laws that agreed as the standard norm in establishing relationships between individuals and individuals, individuals with groups, and groups with groups.

Rationalization of Islam teachings in everyday life is a sign of implementation of modern norms of local inhabitants. Moreover, private law becomes public law due to the expanded interaction among the community. The development of a society that slowly but surely forced 
the law rooted in colonial transforms the evolution of interaction of people who continue to use customary law and religious law, as before the arrival of colonial in the Nusantara.

\section{Research Design}

The method used was abductive with qualitative data analysis using secondary data and in-depth interviews. The secondary data were from various sources, such as journals, books, and internet sources. The journals and books were adopted in assessing and tracing the history of halalan thayyiban food principle in Indonesia.

Blaikie (2007) described abductive research strategy starts from the social actors' point to explain the social world. In-depth interviews were done with respondents from leaders of various beliefs in Banten, which is the largest spot of halal valley industry in Indonesia to strengthen the findings in this research. The respondents were faith-based leaders from Buddhist, Nahdlatul Ulama, Muhammadiyah, and Indonesian Ulama Council (Majelis Ulama Indonesia/MUI) in Banten Province. The interview processes were recorded then transcribed in a verbatim way. Furthermore, the coding process was done and the findings were assessed to answer the objectives. Overall, the result may give new insight into the history of roles of ulama on halalan thayyiban food in Nusantara that can contribute knowledge in halalan thayyiban food law timeline.

\section{Analysis and Discussion \\ Halalan Thayyiban Food Principle at Pre-Colonial}

Knowledge of halalan thayyiban principle, especially in food, emerged in line with the development of Islamic law in Indonesia. Islamic law in Indonesia has long lived within the legal consciousness of the Islamic community in Indonesia along with the growth and development of Islam, and it may trace to the early days of Islam entering Indonesia. Before Islam entered, society cultivated animism and dynamism. Furthermore, along with the entry and emergence of various religions in Indonesia, the empires were built based on the religion they belief. For instance, empires based on Hinduism, Buddhism, and Islamic teachings which supported by guardians and teachers of Islam, namely, the establishment of Demak kingdom and the north coast of Central Java (Hardjono, 2008).

Islamic teachings were not just implemented as a belief, but also as a guide in daily life activities in the kingdom areas that applied the values. It is among others seen from the position of the King/Sultan who has three main functions, namely: (1) The Head of the General Government; (2) Head of Defence and Security, and (3) The administrator of the religion section (Azizy, 1980). Therefore, the titles' king took from the names of Islam at the time, such as; Sampeyan Dalem Hingkang Sinuhun, Senapati Hing Ngalogo, the commander-in-chief of the army, and Sayidin Panatagama Khalifatullah, the caliph of Allah in the field of religion. The symbolization of the three functions performed in the spatial layout of the region. Moreover, the square's existence, palaces (now districts), and mosques in Islamic kingdoms in Java appeared. Such influence is then seen also in the entire structure of government formed. Subsequently, the structure of government formation proved by the position of Kanjeng Penghulu, Penghulu Tuanku Mufti, Tuanku Kadi, in addition to the kings and regents, until the position of Lebai, Modin, Kaum, and so-on in addition to lurah, Head of Nagari/Kampung (Soedarna, 1986).

The acceptance and implementation of Islamic Law in Indonesia were evident in the early Islamic kingdoms. At the time of the Islamic Sultanate, Islamic Law was officially enforced as state law. In Aceh, or during the reign of Sultan Agung, namely, Islamic law was 
enacted even in a simple way (Azizy, 1980). For example, in Banten during the reign of Sultan Agung Tirtayasa, customary law and religious law were implemented as well. In Wajo, Sulawesi, inheritance law conforms to Islamic law. The same thing also happened in the Bone and Goa area of South Sulawesi, used by Kitab Muharrar and Pepakem Cirebon and other regulations made by B.J.D. Clootwijk. Thus, when the VOC (Verenigde Qost Indische Companie) ruled for two centuries (1602-1800 AD), the position of Islamic law remained as it was, prevailing and flourishing among Indonesian Muslims (Hardjono, 2008).

Nuruddin al-Rinary (d. 1077 H / 1666 AD) an Acehnese cleric, was instrumental in spreading Islamic law through a book entitled Sirat al-Mustaqim (straight path) in 1628 AD. This book is the first book distributed throughout Indonesia to become the handle of Muslims in solving their legal problems. The book, by Mufti Banjarmasin, Sheikh Arsyad al Banjary (1122- $1189 \mathrm{H} / 1716-1812$ AD) who had studied in the Middle East, commented in the book titled Sabil al-Muhtadin (the way of the people who got the guidance), which was then used as a handle in resolving disputes between Muslims in Banjar sultanate area. The sultanate of Palembang and Banten also published several books of Islamic law that became the handle in the matter of family law and inheritance, which was then followed by the kingdoms of Demak, Jepara, Tuban, Gresik, and Ngampel (Surabaya) (Hardjono, 2008).

People at the kingdom period interacted to fulfill their food needs of halalan thayyiban foods based on customary and religious laws that prevailed. To meet their food needs as a source of food security for the sake of survival, they did agricultural processes, livestock, fisheries, irrigation, plantations, and trade following the traditional and religious values that were taught by the ancestors. Moreover, it was done privately, without any interference from the authorities.

The Muslim community that developed in Indonesia has social interactions with Hindu and Buddhist people and others who have been present in the archipelago. Social engagement has been carried out through community relations, where non-Muslim communities know and respect Islamic values. The acceptance of pluralism emerged with tolerance implementation on halalan thayyiban food availability carried out among the faithbased community at the time, as presented by Buddhist leaders in Banten as follow, ${ }^{1}$

In the old days, the Chinese realized that they have to present halal food for Muslim guests at a party or an event. There must be two separate tables presented between halal and haram food. The event organizer understands the law regarding the cuisine of Muslims. Eventually, they will separate the raw materials, the cooking utensils, the cooking process, and the cook from haram things.

The implementation of Muslim and non-Muslim interactions in the fulfillment of halalan thayyiban food was carried out with religious tolerance at that time.

\section{Halalan Thayyiban Food During Colonial}

Halalan-thayyiban food law in the era of colonial is carried out based on customs or customs based on Islamic law, which it has been running in the community. The rules in a structured manner in the legislation have not been formulated, so the people learn,

\footnotetext{
${ }^{1}$ Based on the results of an in-depth interview with Romo of Buddhists in Banten Province as a Public Relations Vihara Avalokitesvara Banten, and he concurrently serves as a Buddhist Extension Officer in Banten Province, 21/08/2019, 10.30-13.00 WIB.
} 
understand, and implements halalan thayyiban food principle comes from teachers, scholars, and parents.

The Dutch never attacked the Islamic kingdoms directly, but the Dutch took advantage of internal conflicts and imposed agreements, and subsequently carried out devide et-empera politics. The struggle against colonial invaders involves a physical strive with the leadership, namely the bureaucratic elites and clerics, without touching the affairs or rules related to food law (Ambary, 1998). Furthermore, Dutch policy towards Islam and Islamic law in Indonesia can be divided into two periods. The first was the period of VOC rule from 1596 to the mid19th century. This period was interspersed with the Reign of England in 1811-1816 AD. The second was the mid-19th century until the end of Dutch rule in Indonesia (Iqbal, 2009).

The position of Islamic Law during the VOC lasted for approximately two centuries. However, when the VOC government ended, and Dutch's rule regulated the Indonesian archipelago, its attitude to Islamic law changed gradually and systematically. In the time of Daendels (1808-1811), the change began. At that time, Islamic law was the original law of indigenous peoples. Daendels issued a regulation stating that the religion of Javanese and its natives should not be disturbed. He also asserted the position of the chief (penghulu) as an expert of Islamic law (Suntana, 2014).

According to the law experts, Salomon Keyzer (1823-1868) and Lodewijk Christian van den Berg (1845-1927) held that the law prevailed among the Javanese and other islands followed the religion that adopted by local people. If he converts to Islam, it is the law of Islam that applies to him. That is, Islamic law becomes customary law in the community. Their opinions helped Dutch Indies government officials get to know the Islamic law that applies among the Islamic community. Ali (2013) stated Van den Berg wrote on Islamic law according to the Syafi'i and Hanafi sects in 1884, and later he wrote about family law and Islamic inheritance law in Java and Madura with some irregularities in 1902. He also recommended that Islamic law be carried out by Dutch judges, with the support of Islamic rulers and or Islamic scholars.

In the 19th century until independence, although the Dutch colonial government had interfered a lot in the affairs of Muslims in politics and economy, Islamic law was still implemented by the Muslim community of the Archipelago, including the existence of a religious judiciary with the authority of clerics as an institution of dispute resolution between Muslims remained. Thus, the Dutch colonial government could not eliminate or even remove the existence of Islamic law. It has given the reality of the Muslim archipelago community that has long used the religious judiciary not only as a legal institution in resolving disputes but also has become a robust Islamic identity as a custodian of the continuity of Islamic law in the Archipelago related to inheritance, marriage, and others, including food issues (Aripin, 2013).

The sources of halalan thayyiban food law used are al-Quran, and Al-hadith taught through formal and non-formal education. Halalan thayyiban food studies related to how to plant, how to slaughter, how to cook to the manner how to consume are taught culturally. Moreover, it is understood as a law that must be obeyed and valued as worship.

Banten kingdom was known as a kingdom based on Islamic teachings in Nusantara. Nowadays, Banten province is sighted as the first largest halal industry in Indonesia. Furthermore, halalan thayyiban food in Banten carried out long before Indonesia became independent,

All stakeholders must involve in realizing Banten as the center of the halal industry. Furthermore, Banten is known as a recognized trading center during the leadership of Sultan Hasanuddin. 
Moreover, Islamic teachings spread under the first sultan in Banten, In the era of the first sultan of Banten, Maulana Hasanuddin (1527-1570) began to establish an Islamic kingdom in Banten since the takeover of power by the kingdom of Demak. During the sultanate of Maulana Hasanuddin, it controlled both sides of the Sunda strait and extended to South Sumatera. During his time, the Sultanate of Banten showed significant progress as an Islamic kingdom in the Nusantara (Anggraheni, Attamimi, \& Jumardi, 2020).

The habit that Muslims do in everyday activities on halalan thayyiban food evolves into customary law in the local neighborhood in Banten. As said by a Muslim leader from Muslimat Nahdlatul Ulama at Banten Province that, The theory of reception explains that Islamic principles were allowed as customary law. There is a rebuttal to the thought that Islamic law is unacceptable before the reception by customary law. Such rebuttal is that customary law is unsuitable if it is contrary to Islamic law. Muslims were robust to uphold the teachings of their belief so that the teachings of the religion become habitual, cultured, and finally accepted by customary law.

\section{Halalan Thayyiban Food in Post-Colonial}

Food regulation for the fulfillment of food security in Indonesia has undergone evolution after the arrival of the colonial. It happens because of the increasing population growth so that the need for land for housing is increasing, and this causes the transfer of land functions from agricultural land, plantations, and fisheries into residential areas, even industrial areas, as a result of the current globalization in economic development locally, regionally and internationally. It causes the fulfillment of quality food to be hampered. Arrangements that initially used customary and religious laws seemed to be eliminated by the performance of legal arrangements through the regulation under the pretext of protecting citizens using the legal system they carry and apply in the country (Mudiono \& Wasino, 2015). However, problems in colonial times related to food regulation established, for example, during the colonial period in Indonesia occurred,

Demands on the production of peasants through mastery of land use have been a problem since the early days of colonial. Discussions about the nature of land ownership and about how the agrarian base are burdened by taxes, which have been started since the late 18th century and continued until the early 20th century which is of colonial importance (Mudiono \& Wasino, 2015).

The interruption of colonial in food regulation leads to disharmony of interaction in society. Public law takes a role to conduct rules to protect Muslims in obtaining food products following Islamic sharia. Furthermore, food law in Indonesia requires halal logos for food products for Muslims. The Act is Act No. 18/2012 on Food. In addition, halal and haram of agricultural food products described that,

All agriculture products, vegetables, and fruits may be eaten, except those that bring harm or intoxication, either directly or through the process, then all kinds of plants containing toxins or intoxicating are forbidden to eat (Zulham, 2018).

Regulations based on religious norms -to protect faith-belief communities- are gradually applied in public law. The Food Law explanation mentioned that halal certification for a halal food product is essential for Indonesians who embrace Islam (Nikmah, 2015). Ulama in Banten said that in Indonesia, halal certification for products is required, 
The law formed to construct religious values in halal products was finally conducted and passed in 2014, by establishing Act No. 33/2014 on Halal Product Assurance with the Indonesian Ulama Council as an authoritative holder on the halal fatwa.

Government establishes halal regulations to protect Muslim consumers. In terms of halalan thayyiban food products quality assessment, producers become the main subject to guarantee the quality of products in every level of production stages. Based on the food law, food in Indonesia must not conflict with religion, beliefs, and culture of the community as refered to the Table 1 below.

Table 1: Non-conflicted Requirements on Food Law

\begin{tabular}{|c|c|c|}
\hline No & Article(s) & Description \\
\hline 1 & $1(4)$ & $\begin{array}{l}\text { Food Security is the fulfillment of Food from the state level down to the } \\
\text { individuals, that is reflected by sufficient food availability, both in } \\
\text { quantity and quality, safe, diverse, nutritious, prevalent and affordable } \\
\text { as well as not conflicting with religion, belief and culture, to live healthy, } \\
\text { active and productive in a sustainable manner. }\end{array}$ \\
\hline 2 & $37(1)$ & $\begin{array}{l}\text { Food Import implemented to fulfill domestic consumption necessity } \\
\text { must fulfill the requirement of safety, quality, nutrition and not in conflict } \\
\text { with religion, belief or culture. }\end{array}$ \\
\hline 3 & 48 (1) (b) & $\begin{array}{l}\text { Food Distribution as intended in Article } 47 \text { is performed through: } \\
\text { (b) management of Food distribution system that maintains security, } \\
\text { quality, nutrition and not in conflict with religion, belief and culture. }\end{array}$ \\
\hline 4 & 59 (b) & $\begin{array}{l}\text { Government and Regional Government must increase the quantity and } \\
\text { quality of Food consumption for the people through: } \\
\text { (b) Diverse Food provision, nutritionally balanced, safe and not in conflict } \\
\text { with religion, belief, and culture; }\end{array}$ \\
\hline 5 & $67(1)$ & $\begin{array}{l}\text { Food Safety is implemented to maintain Food to be safe, hygienic, } \\
\text { excellent, nutritious and not in conflict with religion, belief and culture. }\end{array}$ \\
\hline 6 & $\begin{array}{l}95 \quad \text { (1) \& } \\
\text { (2) }\end{array}$ & $\begin{array}{l}\text { (1) Government and/or Regional Government performed control on } \\
\text { implementation of halal product guarantee system for Food that } \\
\text { is required. } \\
\text { (2) Implementation of halal product guarantee system for those } \\
\text { required as intended in paragraph (1) is executed according to the } \\
\text { provision of the regulating legislation. }\end{array}$ \\
\hline 7 & $101(1)$ & $\begin{array}{l}\text { Everyone stated on the label that the Food being traded is halal according } \\
\text { to the requirement is responsible for its truth. }\end{array}$ \\
\hline 8 & $105(1)$ & $\begin{array}{l}\text { Everyone stated on the label that the Food being traded is halal according } \\
\text { to the requirement is responsible for its truth. }\end{array}$ \\
\hline
\end{tabular}

Source: Indonesia's Act No.18/2012 on Food 
The resulting food products should not be contrary to the religion, beliefs, and culture of the community has the meaning that among others, food that meets halal requirements for Muslims or food that prohibited from being consumed according to religion, beliefs, and culture of people in Indonesia.

Faridatun Nikmah (2015) explained that processed products -such as food, beverages, medicines, and cosmetics- may be categorized into mutasyabihat (syubhat) groups if the products come from countries where most its population were non-Muslim. Even though, if the raw materials are holy and halal, because it is not closed the possibilities -the process of making- it mixed or using haram materials. Thus, these processed products for Muslims are not a trivial issue, but a big problem. Naturally, Muslims are concerned about getting firm the legal status of these products. So, there is no doubt about purchasing and consuming food products. Therefore, Indonesia reformulated the law on halal products and worthy of consumption, namely Act No. 33 of 2014 on Halal Product Assurance.

The role of scholars in the era of post-colonial related to halal food is to issue halal fatwa(s). Moustafa Kaseem (2011) stated fatwa means to answer a question pertaining to the religious ruling of a particular action. Furthermore, halal product assurance interprets as a legal certainty by issuing a halal certificate. It is a halal product recognition established by the halal agency following the halal fatwa of MUI. A series of MUI fatwa(s) that were published related to halalan thayyiban food products were described in Table 2 below.

Table 2: Fatwa of MUI on Food from Pre-Colonial to Post-Colonial

\begin{tabular}{|c|c|c|}
\hline No & Fatwa/Year & Description \\
\hline 1 & $\begin{array}{l}18 \text { Syafar } 1405 \text { H / } 12 \\
\text { November } 1948 \text { at Masjid } \\
\text { Istiqlal, Jakarta }\end{array}$ & $\begin{array}{l}\text { Fatwa about eating and cultivating frogs. } \\
\text { MUI fatwa commission meeting expanded with several } \\
\text { envoys of the Regional Ulama Council, several deans of the } \\
\text { IAIN sharia faculty, and experts from IPB. }\end{array}$ \\
\hline 2 & $\begin{array}{l}24 \text { Syawal } 1396 \text { H / } 18 \\
\text { October } 1976\end{array}$ & $\begin{array}{l}\text { MUI fatwa Commission on the mechanical slaughter of } \\
\text { animals. }\end{array}$ \\
\hline 3 & $\begin{array}{l}\text { 11-17 Rajab } 1400 \text { H / } 26 \\
\text { May - } 1 \text { June } 1980\end{array}$ & $\begin{array}{l}\text { MUI in the second national meeting on food and beverage } \\
\text { mixed with najis (unclean things). }\end{array}$ \\
\hline 4 & $\begin{array}{l}17 \text { Jumadil Awal } 1403 \mathrm{H} \mathrm{/} \\
12 \text { March } 1983 \text { in Jakarta }\end{array}$ & Commission of MUI fatwa hearing on eating rabbit meat. \\
\hline 5 & $\begin{array}{l}\text { 13-14 Rabi'ul Akhir } 1414 \text { / } \\
30 \text { September } 1993 \text { in } \\
\text { Jakarta }\end{array}$ & $\begin{array}{l}\text { The law of alcohol in beverages. National mudzakaroh on } \\
\text { alcohol in beverage products organized by the Institute of } \\
\text { Food Studies, medicines, and cosmetics of LPPOM-MUI. }\end{array}$ \\
\hline 6 & 16 December 2000 & $\begin{array}{l}\text { Fatwa of halal products determination. } \\
\text { Fatwa Commission of the Indonesian Ulama Council in } \\
\text { Commission meeting with LPPOM MUI, on Wednesday and } \\
\text { Saturday, } 17 \text { \& } 20 \text { Ramadan } 1421 \text { H / } 13 \text { \& } 16 \text { December } \\
2000 \text { M. }\end{array}$ \\
\hline 7 & $01 / 2001$ & $\begin{array}{l}\text { Guidelines for reporting the audit results of slaughtering } \\
\text { animals for flavoring products from PT. Ajinomoto } \\
\text { Indonesia. Determination of Halal Products. }\end{array}$ \\
\hline
\end{tabular}




\begin{tabular}{|c|c|c|}
\hline 8 & $4 / 2003$ & Standardization of halal fatwa \\
\hline 9 & $11 / 2009$ & The law of alcohol \\
\hline 10 & $12 / 2009$ & Halal Slaughter Certification Standards \\
\hline 11 & 30 December 2009 & $\begin{array}{l}\text { Fatwa Decree of the Fatwa Commission of the Indonesian } \\
\text { Ulama Council on the Determination of Halal Products. } \\
\text { Fatwa Commission of Majelis Ulama Indonesia, in a meeting } \\
\text { of the Commission with LPPOM MUI, on Wednesday, } 13 \\
\text { Muharram } 1431 \text { H / } 30 \text { December } 2009 \text { M. }\end{array}$ \\
\hline 12 & $01 / 2010$ & Use of microbes and microbial products in food products. \\
\hline 13 & $07 / 2010$ & Coffee of Civet \\
\hline 14 & $33 / 2011$ & $\begin{array}{l}\text { The law of food and beverage colouring from cochineal } \\
\text { insects. }\end{array}$ \\
\hline 15 & $25 / 2012$ & The law of consuming snails. \\
\hline 16 & $43 / 2012$ & $\begin{array}{l}\text { Misuse of formalin and other hazardous materials in the } \\
\text { handling and processing of fish. }\end{array}$ \\
\hline 17 & $47 / 2012$ & $\begin{array}{l}\text { The use of fur, hair, and horns from halal animals that are } \\
\text { not slaughtered syar'i for foodstuffs, medicines, and } \\
\text { cosmetics. }\end{array}$ \\
\hline 18 & $52 / 2012$ & The law of farm animals that are fed from unclean goods. \\
\hline 19 & $27 / 2013$ & The use of Shellac as foodstuffs, medicines, and cosmetics. \\
\hline 20 & $35 / 2013$ & Genetically engineering and its products. \\
\hline 21 & $36 / 2020$ & $\begin{array}{l}\text { Fatwa on Eid al-Adha prayer and the slaughter of sacrificial } \\
\text { animals during the covid-19 outbreak. }\end{array}$ \\
\hline
\end{tabular}

${ }^{2}$ Accessed on 27/12/20 


\section{Conclusion}

The role of scholar/ulama in spreading Islam is highly respected by the community. In Nusantara, their role in each era is very dominant because they are people who are believed to understand religion, including about halalan thayyiban food law. The history of halalan thayyiban food law in Indonesia's society divides into three times: pre-colonial, colonial, and post-colonial.

The scholars' role, in pre-colonial, carried out the spread of Islamic teachings through the education system in the community. They were teaching the contents of the Quran and Al-hadith, including the principle of halalan thayyiban food. The beginning of halalan thayyiban food law history is from the entry of Islam brought by the merchants, and then the spread was carried out by the scholars. Furthermore, pesantren became a tool for scientific transfer related to Islamic teachings, and people believe in the teaching system built by pesantren.

During colonial, scholars played a full role in determining that food was halal or haram. The study of food law, in particular, is more to private law -when belief-norms implemented without the intervention of colonial rulers. The invaders who came already understood that Islamic law became a culture and customary law in Indonesia. Subsequently, related to halalan thayyiban food law application could not be disturbed. The colonial government did not interfere in the regulation of halalan thayyiban food law.

The role of scholars, in post-colonial is issuing a halal fatwa on products. On its way, Majelis Ulama Indonesia established halal certificates for halal-verified products to provide certainty for Muslim consumers. When a trade has expanded and not only in the Archipelago, halalan thayyiban food commodity has an extensive market share and promises to bring enormous profits. Eventually, the government feels the need to intervene in maintaining and protecting Muslims' rights. Public law on food established by the government as a real action to assure Muslims get their rights. In Indonesia, halal food regulates in Acts of food law and halal product assurance. Institutionalization of halal standard established under public law authority. The authority spread on various departments, such as Halal Product Assurance Organizing Agency (Badan Penyelenggara Jaminan Pangan Halal/BPJPH), The National Agency for Food and Drug Control (Badan Pengawas Obat dan Makanan/BPOM), Assessment Institution of Food, Drugs and Cosmetics Majelis Ulama Indonesia (Lembaga Pengkajian Pangan Obat-obatan dan Kosmetika Majelis Ulama Indonesia/LPPOM-MUI). However, the role of ulama remains as the main decider on halal standards by establishing halal fatwa. Furthermore, it is strengthened by government halal agencies in establishing legalized halal certificates issued.

The glance exposures in Table 3 describe the transformation roles of ulama on halalan thayyiban food law in Indonesia in three periods, namely, pre-colonial, colonial, and postcolonial. 
Table 3: Transformation of ulama's role on Halalan Thayyiban Food Law in Indonesia

\begin{tabular}{|c|c|c|c|}
\hline Role(s) & Pre-Colonial & Colonial & Post-Colonial \\
\hline Focus of Scholar Activity & $\begin{array}{c}\text { - Spreading of } \\
\text { Religion }\end{array}$ & $\begin{array}{l}\text { Determining halal or } \\
\text { halal for food }\end{array}$ & $\begin{array}{c}\text { Fatwa haram or } \\
\text { halal }\end{array}$ \\
\hline Key Nature/Institution & $\begin{array}{l}\text { - Pesantren } \\
\text { - Palace }\end{array}$ & 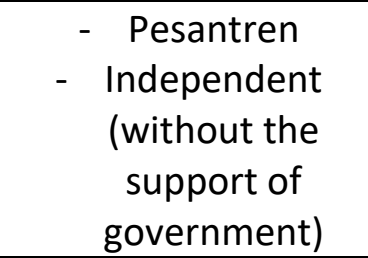 & $\begin{array}{l}\text { Certification of } \\
\text { halal products } \\
\text {-LPPOM-MUI } \\
\text {-BPJPH }\end{array}$ \\
\hline Challenges & $\begin{array}{c}\text { Local culture } \\
\text { adjustment }\end{array}$ & $\begin{array}{l}\text { Local culture } \\
\text { adjustment }\end{array}$ & Globalization \\
\hline Legal Product/Law & $\begin{array}{c}\text { Private food Law } \\
\text { (Fiqh) }\end{array}$ & $\begin{array}{c}\text { Private food law } \\
\text { (Fiqh) }\end{array}$ & $\begin{array}{c}\text { Public Food Law } \\
\text { (Government } \\
\text { take their part } \\
\text { to protect } \\
\text { Muslims for } \\
\text { gaining halal } \\
\text { food) } \\
\text { - Act No. } \\
18 / 2012 \\
\text { - Act No. } \\
33 / 2014\end{array}$ \\
\hline
\end{tabular}

All in all, theorizing about transformation of ulama's role are as follow:

a. The system is the person. In the period of pre-colonial and colonial, ulama take their part to spread Islamic teachings. The fiqh values of halalan thayyiban food evolve into daily life activities of people. Subsequently, the norms transformed into customary law, and the supervisor of its implementation was ulama.

b. The system is the institution. In the post-colonial, ulama is part of the institution of halalan thayyiban food law under public law. Nowadays, ulama's roles have been institutionalized by the system without reducing their authority. Eventually, the institution becomes the system of halalan thayyiban food law.

\section{Acknowledgement}

Great gratitude addressed to the Islamic Development Bank for financial support. We thank our respondents who provided insights and expertise on this paper.

\section{Corresponding Author}

Ikomatussuniah, Centre for Policy Research and International Studies (CenPRIS) Universiti Sains Malaysia, 11800 USM, Pulau Pinang, Malaysia. Email: iko@untirta.ac.id 


\section{References}

\section{Journal article}

Anggraheni, D. S., Attamimi, H., \& Jumardi. (2020). Perkembangan Kerajaan Islam di Banten pada Masa Sultan Ageng Tirtayasa dalam Aspek Politik dan Sosial. Pattinggaloang: Jurnal Pemikiran Pendidikan Dan Penelitian Kesejarahan, 7(2), 146-159.

Hardjono, I. (2008). Hukum Islam di Indonesia dalam Perspektif Sejarah Hukum. SUHUF, 20(1), $1-22$.

Mudiono, \& Wasino. (2015). Perkembangan Tanaman Pangan di Indonesia Tahun 1945-1965. Journal of Indonesian History, 4(1).

\section{Book}

Ali, M. D. (2013). Hukum Islam, Pengantar IImu Hukum dan Tata Hukum Islam di Indonesia. Jakarta: Rajagrafindo Persada.

Ambary, H. M. (1998). Menemukan Peradaban: Jejak Arkeologis dan Historis Islam Indonesia. (J. Burhanuddin, Ed.) (Pertama). Jakarta: Logos Wacana Ilmu.

Aripin, I. J. (2013). Jejak Langkah Peradilan Agama di Indonesia. Jakarta: Kencana Prenada Media Group.

Azizy, A. Q. (1980). Peradilan Islam Batasan Ulasan dan Sejarahnya di Indonesia. Semarang: Fakultas Syariah IAIN Walisongo.

Azra, A. (2013). Jaringan Ulama Timur Tengah dan Kepulauan Nusantara Abad XVII \& XVIII: akar Pembaruan Islam Indonesia (1st ed.). Jakarta: Kencana.

Blaikie, N. (2007). Approaches to Social Enquiry (2nd ed.). Cambridge, UK: Polity Press.

Iqbal, M. (2009). Hukum Islam Indonesia Modern Dinamika Pemikiran dari Fiqh Klasik ke Fiqh Indonesia. Pamulang: Gaya Media Pratama.

Kassem, M. (2014). Fatwa in the Era of Globalization. Ifta' and Fatwa in the Muslim World and the West, 89-104.

Lapidus, I. M. (2000). Sejarah Sosial Umat Islam. Jakarta: Raja Grafindo Persada.

Meulen, B. Van Der. (2011). Private Food Law: Governing Food Chains Through Contract Law, Self-regulation, Private Standards, Audits and Certification Schemes. (B. van der Meulen, Ed.), Wageningen Academic (1st ed.). Wageningen: Wageningen Academic. https://doi.org/10.3920/978-90-8686-730-1

Munoz, P. M. (2009). Kerajaan-Kerajaan Awal Kepulauan Indonesia dan Semenanjung Malaysia: Perkembangan Sejarah dan Budaya Asia Tenggara (Jaman Pra Sejarah-Abad XVI). (Adve, Ed.) (1st ed.). Yogyakarta: Mitra Abadi.

Pires, T. (1944). The suma oriental of Tomé Pires. An account of the east, from the Red Sea to Japan, written in Malacca and India in 1512-1515 and the Book of Francisco Rodrigues rutter of a voyage in the Red Sea, nautical rules, almanac and maps, written and drawn in the. Hakluyt Society (Second Ser, Vol. I). London: McGill University Library.

Soedarna, D. (1986). Sejarah Peradilan Islam. Pekalongan: Fakultas Syari'ah IAIN Walisongo.

Suntana. (2014). Politik Hukum Islam. Bandung: Pustaka Setia.

Tjandrasasmita, U. (2009). Arkeologi Islam Nusantara (Cetakan Pe). Jakarta: KPG (Kepustakaan Populer Gramedia).

Zulham. (2018). Peran Negara dalam Perlindungan Konsumen Muslim Terhadap Produk Halal (1st ed.). Jakarta Timur: Kencana. 
INTERNATIONAL JOURNAL OF ACADEMIC RESEARCH IN BUSINESS AND SOCIAL SCIENCES

Vol. 11, No. 4, 2021, E-ISSN: 2222-6990 @ 2021 HRMARS

\section{Thesis}

Nikmah, F. (2015). Penetapan Fatwa Halal Produk Makanan Minuman Olahan. Universitas Islam Negeri Walisongo Semarang. 